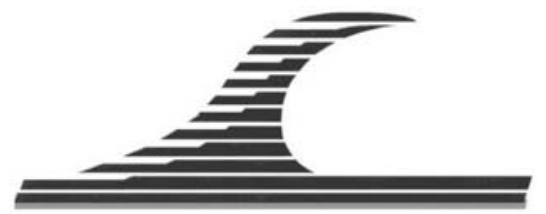

\title{
Formation, evolution and characteristics of karstic estuaries - the Adriatic example
}

\author{
Igor FELJA ${ }^{1}$, Mladen JURAČIĆ ${ }^{1}$
}

1. University of Zagreb, Faculty of Science, Department of Geology, Horvatovac 102a, 10000 Zagreb, Croatia.

igorfelja@geol.pmf.hr,mjuracic@geol.pmf.hr

\begin{abstract}
:
The coastal area of the eastern Adriatic is characterized by a prevalence of carbonate rocks and well-developed karst. Present freshwater input into the Adriatic is quite large, mostly through coastal and submarine springs (vruljas). However, there are also a number of rivers debouching in the Adriatic along the eastern coast. Most of them have canyon like fluviokarstic valleys that were carved dominantly during Pleistocene and were drowned during post-Last Glacial Maximum sea-level rise. This caused formation of estuaries which were gradually filled to a different extent during Holocene highstand (last 7.500 years). The intraestuarine delta progradation was rather different in those estuaries depending on the quantity of the river-borne material. Human impact on progradation rate in some of the estuaries has been shown.
\end{abstract}

Article issu d'une sélection des XVèmes Journées Nationales Génie Côtier Génie Civil qui se sont tenues à La Rochelle du 29 mai au 31 mai 2018. Soumis le 29 mai 2018, accepté le 31 mai 2018, en ligne le 15 octobre 2018.

How to cite this paper:

FELJA I., JURAČIĆ M. (2018). Formation, evolution and characteristics of karstic estuaries - the Adriatic example. Revue Paralia, Vol. 11, pp s02.1-s02.07.

DOI: https://doi.org/10.5150/revue-paralia.2018.s02 
s02.2 : Revue Paralia - Vol. 11 (2018)

\section{Formation, évolution et caractéristiques des estuaires karstiques Exemple de l'Adriatique}

\section{Résumé :}

La zone côtière de l'Adriatique orientale est caractérisée par une prédominance de roches carbonatées et de karst bien développé. Les apports actuels d'eau douce dans l'Adriatique sont assez importants, principalement à travers les sources côtières et sousmarines (vruljas). Cependant, il y a aussi un certain nombre de rivières qui débouchent dans l'Adriatique le long de la côte orientale. La plupart d'entre elles ont des vallées fluvio-karstiques qui ont été sculptées de façon dominante au cours du Pléistocène et ont été noyées pendant l'élévation maximale du niveau de la mer après le dernier épisode glaciaire. Cela a provoqué la formation d'estuaires qui ont été progressivement remplis à un degré différent au cours de l'Holocène (ces 7.500 dernières années). La progradation du delta intra-estuarien était plutôt différente dans les estuaires en fonction de la quantité de matériel véhiculé par la rivière. L'impact humain sur le taux de progradation dans certains des estuaires a été démontré.

\section{Mots clés:}

Estuaires, Sédimentation, Delta intra-estuarien, Progradation, Rivière allogénique, Influence anthropique. 


\section{Introduction}

Eastern Adriatic coastal area was formed predominantly in Mesozoic carbonate rocks with well-developed karst (PIKELJ \& JURAČIĆ, 2013). Due to prevalent humid climatic conditions and karst maturation present freshwater input into the Adriatic is large, mostly through coastal and submarine springs (vruljas). However, there are also a number of rivers debouching into the Adriatic. These rivers have some common characteristics, but also differences. Obviously, they have fluvio-karstic valleys which have been drowned by the sea-level rise during post-Late Glacial Maximum (LGM) transgression. So formed (karstic) estuaries were gradually filled with river-borne, predominantly siliciclastic material. The aim of this paper is to present and discuss common and specific characteristics and differences of Adriatic karstic estuaries and to indicate a human influence on their evolution.

\section{Formation of the present river mouths}

The karstic, canyon-like, valleys of rivers debouching into the Adriatic were incised and/or remodeleled during LGM sea level lowstand. However considering that the depths of some of the karstic river valleys close to the river mouths are deeper than minimum sea-level during LGM ( 120 m below msl) (FELJA, 2017), they must have beeen incised earlier (in Quaternary) or even in Miocene (Messinian salinity crisis). Therefore, during LGM, Paleo-rivers were eroding older deposits, possibly reaching carbonate basement and/or further incising their valleys. Transgression after LGM caused flooding of the valleys and deposition of transgressive sands and silts, followed by Holocene highstand marine/estuarine deposition and progradation of intra-estuarine deltas and, in some cases, completely filling former valleys with alluvial material and development of recent delta plains.

\section{Evolution of karstic estuaries}

Rivers debouching into the Adriatic sea along the eastern coast have lower reaches of their valleys carved in carbonates (predominately Cretaceous and Eocene limestone), whereas upper part of their catchment area was formed either in flysch (e.g. rivers Dragonja, Mirna, Raša, Rječina, Jadro) or in other impermeable rocks (clastics, magmatic \& metamorphic rocks) (e.g. rivers Nerteva, Krka, Zrmanja) (JURAČIĆ, 1998). Therefore the term allogenic karstic rivers can be applied to them.

Most of the rivers in lower reaches have well-developed canyon-like valleys (JURAČIĆ \& PROHIĆ, 1991; JURAČIĆ, 1992). These fluviokarstic valleys were presumably carved dominantly in Pleistocene (BENAC et al., 2013), while the sea-level was up to $120 \mathrm{~m}$ lower than the present one. During post-LGM sea-level rise (between 19.000 to 7.500 y BP) the sea drowned these valleys and karstic estuaries were formed. Example of the Raša River valley carved into Cretaceous limestone is shown in figure 1. 


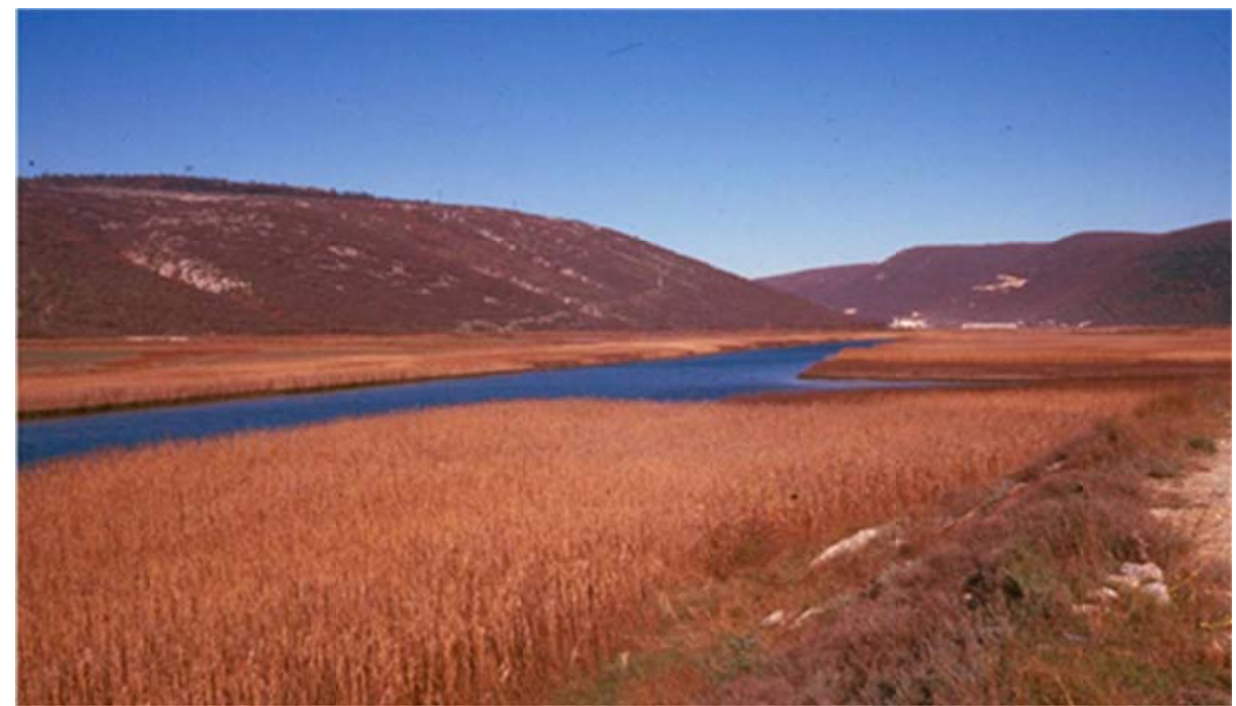

Figure 1. Raša River valley carved in Cretaceous limestone with prograding intraestuarine delta.

\section{Intraestuarine delta progradation}

After the sea-level rise ceased (7.500 yBP), gradual filling of estuaries with river-borne material started. This material is predominantly alumosilicate reflecting lithology of the catchment area. The degree of intraestuarine ("bayhead") delta progradation (SEMENIUK \& SEMENIUK, 2016) is rather different, depending on the quantity of the river-borne material. Two end member examples are Krka River estuary without intraestuaerine delta, and Neretva River mouth with fully developed delta in the former estuary are shown in figure 2.

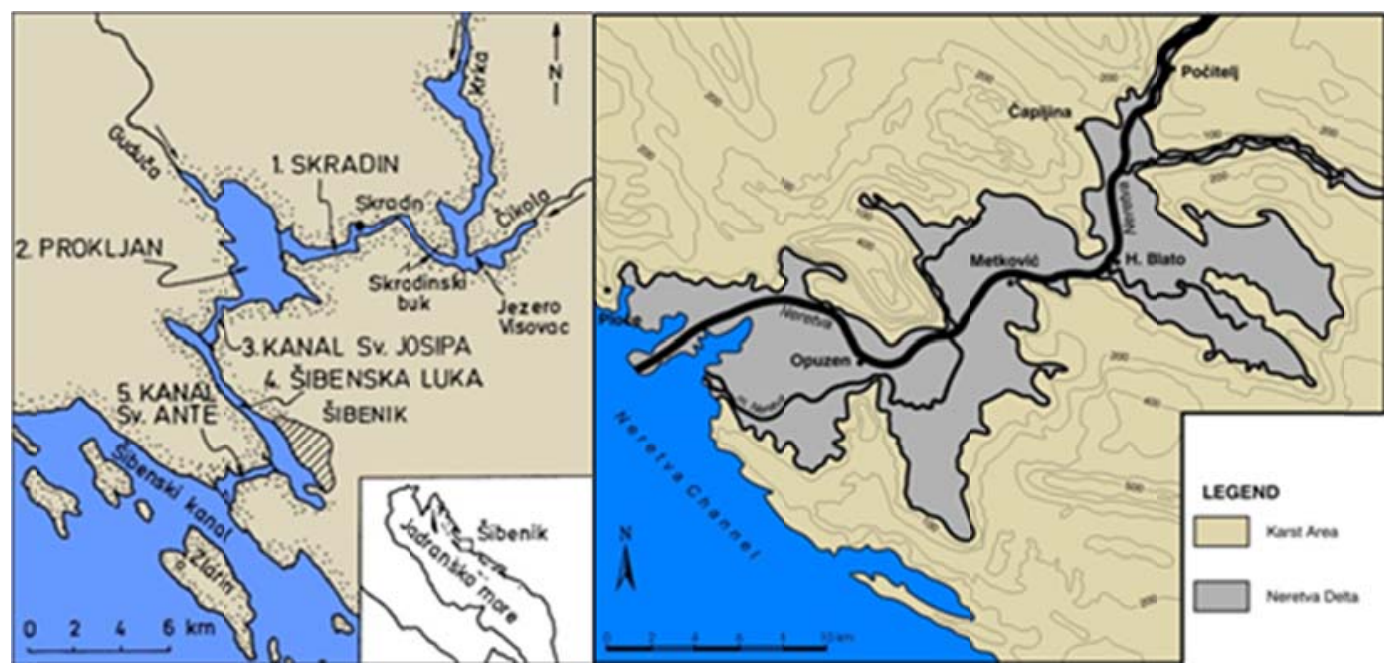

Figure 2. Comparison of the Krka River mouth (deep karstic estuary; left) and Neretva River mouth

(intraestuarine deltaic sediments filled former river valley-estuary; right). 
The main factor governing the formation and progradation of the intraestuarine delta is size and weathering rate of the noncarbonated part of the catchment area on one hand, and formation and existence of in the river watercourse on the other. For example Krka and Zrmanja rivers have a rather small part of the catchment developed in noncarbonate rocks, and have well-developed calc tufa barriers along the watercourse, and therefore have no intrestuarine delta (JURAČIĆ \& PROHIĆ, 1991; JURAČIĆ, 1992). Therefore, Zrmanja and Krka are examples of give up estuaries, according to the Cooper classification (COOPER et al., 2011). On the other hand, Mirna and Neretva estuaries can be classified as catch up estuaries (COOPER et al., 2011), with the final phase of progradation of intra-estuarine deltas. Neretva intraestuarine delta quite completely filled former Neretva estuary, whereas seaward end of the Mirna estuary is still not completely filled, forming the recent Mirna Bay. In the Holocene highstand, last 6500 years, an intraestuarine delta sequence prograded for over $11 \mathrm{~km}$ in the lower tract of the Mirna River (figure 3), filling the pre-existing valley with a sediment thickness of at least 30 m (JURAČIĆ, 1998; FELJA et al., 2015; FELJA, 2017).

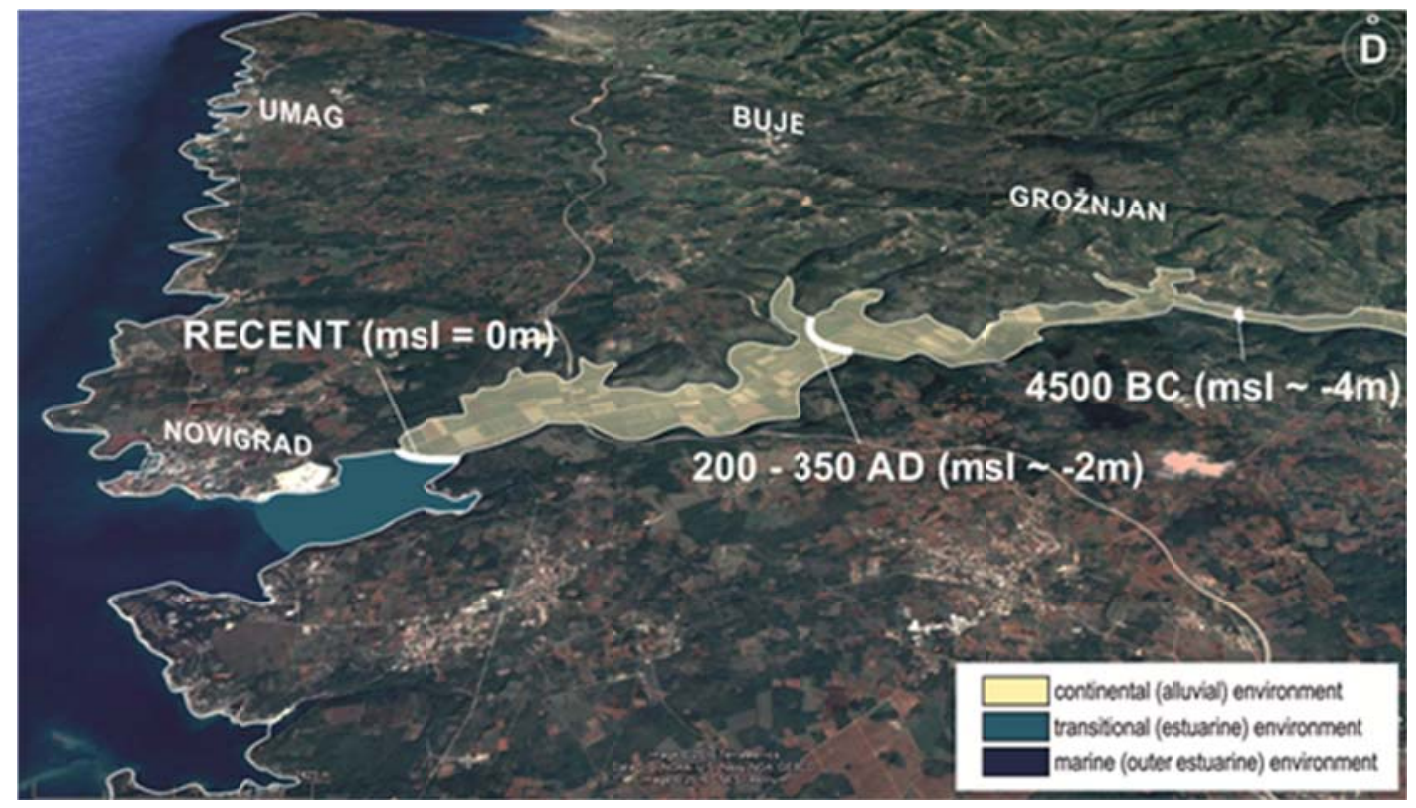

Figure 3. Progradation of the Mirna intraestuarine delta in the last 6500 years.

Transitional and marine environment shifted accordingly. Modified after FELJA et al., 2015 and FELJA, 2017.

An example of the partially filled estuary is the Raša River mouth, where delta progradation of $2 \mathrm{~km}$ in 200 years has been documented (BENAC et al., 1991; SONDI et al., 1995) (figure 4). Due to the fact that in the catchment of both Mirna and Raša rivers dominate flysh with a large share of marl, both intraestuarine deltas are characterized with fine-grained muddy sediments (SONDI et al., 1995; FELJA et al., 2015). 

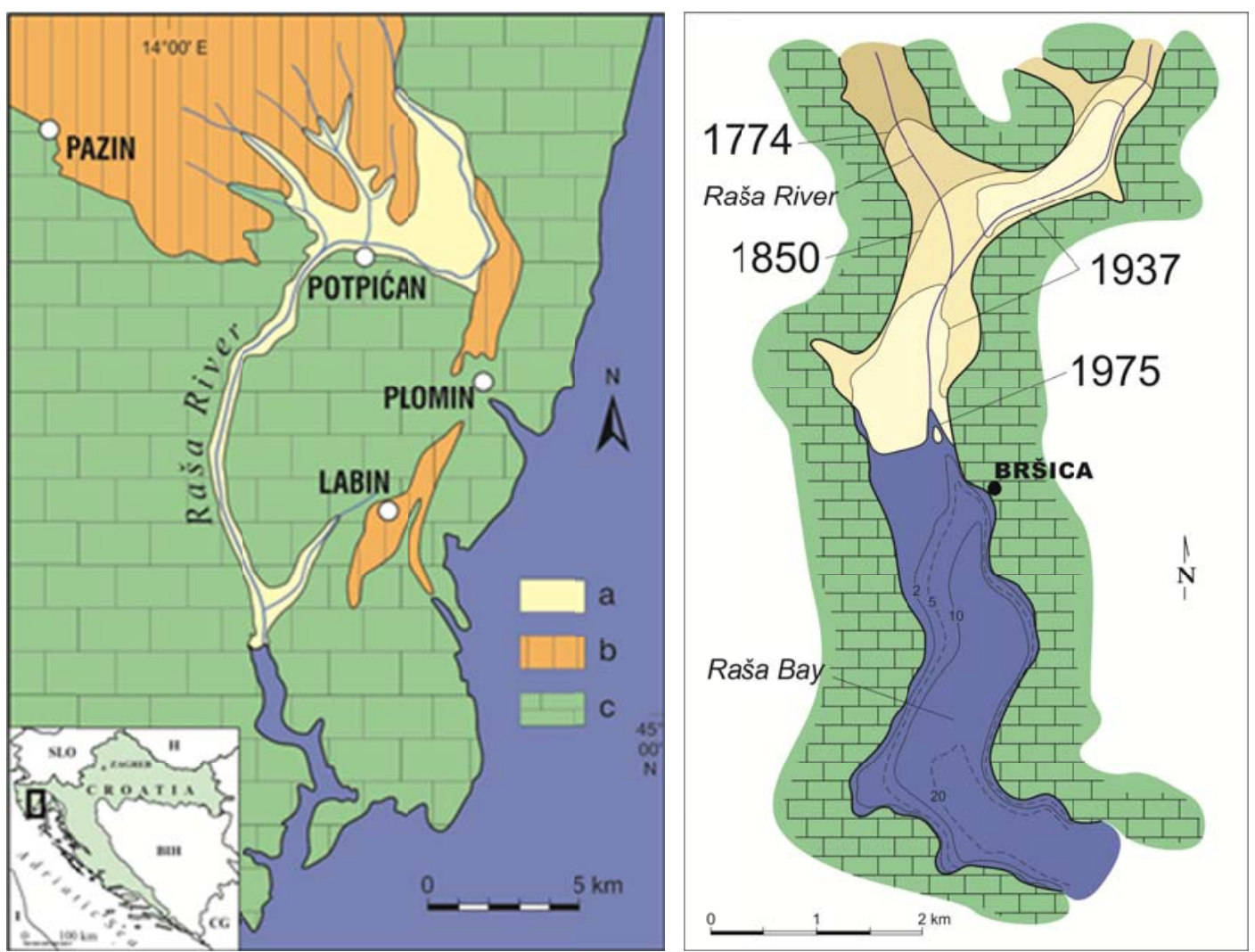

Figure 4. The Raša River catchment lithology ( $a=$ Quaternary alluvial sediments; $b=$ Eocene flysch (marl and sandstone); $c=$ Cretaceous and Eocene limestone) on the left, and Raša River intraestuarine delta progradation (after BENAC, 1991) on the right).

\section{Anthropogenic impact}

Investigation of the sedimentation in karstic river mouths along the Adriatic coast revealed that human impact on some of them is rather large. In the case of the Mirna River estuary, its intraestuarine delta progradation was accelerated firom $15^{\text {th }}$ to $19^{\text {th }}$ century due to deforestation and agriculturization of the catchment area, which caused much faster erosion of flysch terrains (FELJA, 2017). The opposite, deceleration of Neretva river delta progradation and accumulation of much finer sediments occurred during the $20^{\text {th }}$ century due to damming of upper reaches of the river in order to build hydropower plants, along with intensive melioration (JURAČIĆ, 1998).

\section{Conclusions}

Karstic character of the eastern Adriatic coast caused the formation of peculiar river mouths which can be termed karstic estuaries. Their common characteristics are that fluviokarstic river valleys carved and remodeled in carbonates were flooded during post-LGM sea-level rise forming long elongated estuaries. The degree of their filling with prevalently siliciclastic material depends mostly on the intensity of allogenic 
riverine input. Therefore these estuaries can remain long narrow estuaries (e.g. Krka and Zrmanja rivers) be partially filled (e.g. Raša River), or can be almost filled forming large delta plains (e.g. Mirna and Neretva rivers). Anthropogenic influence on its development can be substantial.

\section{References}

BENAC ᄃ̌., ARBANAS Ž., PAVLOVEC E. (1991). Origin and geotechnical characteristics of the Raša valley and bay (in Croatian), Pomorski zbornik, Vol. 29, pp 475-429.

BENAC Č., JURAČIĆ M., MATIČEC D., RUŽIĆ I., PIKELJ K. (2013). Fluviokarst and classical karst: Examples from the Dinarics (Krk Island, Northern Adriatic, Croatia). Geomorphology, Vol. 184, pp64-73. https://doi.org/10.1016/j.geomorph.2012.11.016

COOPER J. A. G., GREEN A.N. \& WRIGHT C. I. (2011). Evolution of an incisedvalley coastal plain estuary under low sediment supply: a "give-up" estuary. Sedimentology, Vol. 59, pp 899-916. https://doi.org/10.1111/j.1365-3091.2011.01284.x.

FELJA I., FONTANA A., FURLANI S., BAJRAKTAREVIĆ Z., PARADŽIK A., TOPALOVIĆ E., ROSSATO S., ĆOSOVIĆ V., JURAČIĆ M. (2015). Environmental changes in the lower Mirna River valley (Istria, Croatia) during the Middle and Late Holocene. Geologia Croatica, Vol. 68 (3), pp 209-224. https://doi.org/10.4154/gc.2015.16

FELJA I. (2017). Karstic estuaries along the eastern Adriatic coast: Late-Quaternary evolution of the Mirna and Neretve River mouths. PhD Thesis, University of Zagreb, Croatia, $169 \mathrm{p}$.

JURAČIĆ M., PROHIĆ E. (1991). Mineralogy, sources of particles, and sedimentation in the Krka River estuary. Geološki Vjesnik, Vol. 44, pp 195-200.

JURAČIĆ M. (1992). Sedimentation in some Adriatic karstic river mouths. (Are they estuaries or rias?). Proceedings of the conference Geomorphology and the sea, Mali Lošinj, 1992. Department. of Geography, Faculty of Science, University of Zagreb, pp 55-63.

JURAČIĆ M. (1998). O nastanku i promjenama delte rijeke Neretve. Dubrovnik, Časopis za književnost $i$ znanost, Nova serija, god. Vol. IX (4), Matica hrvatska Dubrovnik, pp 228-232.

PIKELJ K., JURAČIĆ M. (2013). Eastern Adriatic Coast (EAC): Geomorphology and Coastal Vulnerability of a Karstic Coast. Journal of Coastal Research, Vol. 29 (4), pp 944-957. https://doi.org/10.2112/JCOASTRES-D-12-00136.1

SEMENIUK V., SEMENIUK C. (2016). Deltas. In Kennish M. J. ed., Encyclopedia of Estuaries, Springer References, Dodrecht, pp. 177- 187. https://doi.org/10.1007/978-94-017$\underline{8801-4}$

SONDI I., JURAČIĆ M., PRAVDIĆ V. (1995). Sedimentation in a disequilibrium river-dominated estuary. The Raša River Estuary (Adriatic Sea-Croatia). Sedimentology, Vol. 42, pp. 769-782. https://doi.org/10.1111/j.1365-3091.1995.tb00408.x. 